\title{
Donor-derived Interferon $\gamma$ Is Required for Inhibition of Acute Graft-versus-Host Disease by Interleukin 12
}

\author{
Yong-Guang Yang, Bimalangshu R. Dey, Justin J. Sergio, Denise A. Pearson, and Megan Sykes \\ Bone Marrow Transplantation Section, Transplantation Biology Research Center, Surgical Service, Massachusetts General \\ Hospital/Harvard Medical School, Boston, Massachusetts 02129
}

\begin{abstract}
We have demonstrated that a single injection of interleukin (IL)-12 on the day of bone marrow transplantation (BMT) inhibits acute graft-versus-host disease (GVHD) in mice. This effect of IL-12 can be diminished by anti-interferon (IFN)- $\gamma$ mAb. To determine the mechanism by which IFN- $\gamma$ affects IL-12-mediated GVHD protection, we have compared the effect of IL-12 on GVHD in C57BL/6 wild-type (WT) or IFN- $\gamma$ gene knockout (GKO) recipients of fully major histocompatibility complex plus minor antigen-mismatched allogeneic BMT from WT or GKO BALB/c mice. Lethal acute GVHD was readily induced in the absence of IFN- $\gamma$. IL-12 inhibited GVHD mortality to a similar extent in WT and GKO recipients of WT allogeneic BMT. However, neither WT nor GKO recipients were protected by IL-12 from GVHD induced by GKO allogeneic BMT. Moreover, the effective inhibition of host-reactive donor $\mathrm{T}$ cell activation and expansion that is associated with IL-12-mediated GVHD protection was dependent on the ability of BALB/c donors to produce IFN- $\gamma$. These results demonstrate that (a) acute GVHD can be induced in the absence of IFN- $\gamma,(b)$ host IFN- $\gamma$ does not play a critical role in IL-12-induced GVHD protection, and (c) the protective effect of IL-12 against GVHD is dependent on the ability of the donor to produce IFN- $\gamma$. (J. Clin. Invest. 1998. 102:2126-2135.) Key words: bone marrow transplantation - lethal irradiation • cytokine $\cdot \mathrm{T}$ cell activation $\cdot$ mice
\end{abstract}

\section{Introduction}

IL-12 induces T helper (Th1) ${ }^{1}$-associated responses by stimulating $\mathrm{T}$ cells and natural killer (NK) cells to produce IFN- $\gamma$

\section{Address correspondence to Megan Sykes, Bone Marrow Transplan- tation Section, Transplantation Biology Research Center, Massachu- setts General Hospital, MGH East, Bldg. 149-5102, 13th St., Boston, MA 02129. Phone: 617-726-4070; FAX: 617-724-9892; E-mail: sykes@ helix.mgh.harvard.edu \\ Received for publication 21 August 1998 and accepted in revised form 29 October 1998.}

1. Abbreviations used in this paper: $\mathrm{BMC}$, bone marrow cells; BMT, bone marrow transplantation; CTL, cytotoxic T lymphocyte; FCM, flow cytometry; GKO, IFN- $\gamma$ gene knockout; GVHD, graft-versushost disease; LDA, limiting dilution analysis; MST, median survival time; NK, natural killer; TCD, T cell-depleted; Th, T helper; VLA, very late activation; $\mathrm{WT}$, wild-type.

J. Clin. Invest.

(C) The American Society for Clinical Investigation, Inc. 0021-9738/98/12/2126/10 \$2.00

Volume 102, Number 12, December 1998, 2126-2135

http://www.jci.org
(1-4). Recent studies in a parent $\rightarrow$ nonirradiated F1 bone marrow transplantation (BMT) model have shown that IL-12 plays a critical role in the development of acute graft-versushost disease (GVHD; references 5-7). In contrast, we have recently demonstrated that a single injection of IL-12 on the day of BMT paradoxically inhibits acute GVHD in lethally irradiated mice receiving fully allogeneic or haploidentical BMT (810). This GVHD protection is associated with a reduction in the GVHD-associated expansion and activation of donor Th cells reacting to host antigens (11).

IFN- $\gamma$, the production of which is regulated by IL-12 $(1,2$, $4)$, plays an important role in mediating the biological effects of IL-12 (12-15). Previous reports on the role of IFN- $\gamma$ in acute GVHD have been conflicting. In contrast to studies showing an important role for IFN- $\gamma$ in the induction of GVHD (16-20), exogenous IFN- $\gamma$ has been previously shown to inhibit GVHD (21). Also, despite studies suggesting an important role for IFN- $\gamma$ in the pathogenesis of GVHD-associated immunodeficiency (22-25), IFN- $\gamma$ has been shown to improve immunocompetence (26) and protect from infections (27) in allogeneic BMT recipients. We have recently reported that IL-12 treatment has a biphasic effect on serum IFN- $\gamma$ levels in murine GVHD models, leading to an early increase on days 2 and 3, followed by an almost complete inhibition on day 4 , when serum IFN- $\gamma$ levels peak in untreated GVHD controls (8). IL-12-mediated GVHD protection can be completely abolished by administration of neutralizing anti-IFN- $\gamma \mathrm{mAb}$ (9), indicating that IFN- $\gamma$ plays an essential role in the inhibitory effect of IL-12 on GVHD.

We have now made use of IFN- $\gamma$-deficient mice to determine the mechanism by which IFN- $\gamma$ mediates the protective effect of IL-12 against GVHD and to determine whether donor- or host-derived IFN- $\gamma$ is responsible for this effect of IL12. The results show that IL-12-mediated GVHD protection is dependent on donor-derived IFN- $\gamma$ production. Inhibition of GVHD-associated activation of antihost Th responses related to IL-12 treatment in recipients of wild-type (WT) BALB/c BMT was significantly reduced in recipients of IFN- $\gamma$ gene knockout (GKO) BALB/c BMT. Thus, donor-derived IFN- $\gamma$ plays a critical role in the inhibition of donor Th responses associated with IL-12-induced GVHD protection. Furthermore, our studies show definitively that lethal acute GVHD can develop in lethally irradiated mice in the complete absence of IFN- $\gamma$.

\section{Methods}

Mice. Specific pathogen-free WT and GKO female C57BL/6 (B6, $\left.\mathrm{H}-2^{\mathrm{b}}, \mathrm{K}^{\mathrm{b}} \mathrm{I}^{\mathrm{b}} \mathrm{D}^{\mathrm{b}}\right)$ and $\mathrm{BALB} / \mathrm{c}\left(\mathrm{H}-2^{\mathrm{d}}, \mathrm{K}^{\mathrm{d}} \mathrm{I}^{\mathrm{d}} \mathrm{D}^{\mathrm{d}}\right)$ mice were purchased from the Frederick Cancer Research Facility (National Institutes of Health, Bethesda, MD) and the Jackson Laboratory (Bar Harbor, $\mathrm{ME}$ ). Mice were housed in sterilized microisolator cages and received autoclaved food and drinking water. 
$B M T$. Recipient mice were lethally irradiated $\left(9.75 \mathrm{~Gy},{ }^{137} \mathrm{Cs}\right.$ source, $0.89 \mathrm{~Gy} / \mathrm{min}$ ) and reconstituted within 4 to $8 \mathrm{~h}$ with a single 1 -ml intravenous inoculum containing $5 \times 10^{6} \mathrm{~T}$ cell-depleted (TCD) B6 bone marrow cells (BMC), $7.5 \times 10^{6} \mathrm{BALB} / \mathrm{c} \mathrm{BMC}$, and $20 \times 10^{6}$ $\mathrm{BALB} / \mathrm{c}$ spleen cells, or with $5 \times 10^{6} \mathrm{TCD}$ B6 BMC alone (syngeneic control group). $\mathrm{T}$ cell depletion was performed by incubating cells with anti-CD4 mAb (GK1.5 ascites) and anti-CD8 mAb (2.43 ascites) followed by rabbit complement (28). The completeness of depletion was verified by flow cytometry (FCM) as previously described (10). In one experiment (see Fig. 3), B6 mice received $5 \times 10^{6}$ B6 TCD BMC plus CD4 cell-depleted (with GK1.5 plus complement) or rabbit complement-treated BALB/c BMC $\left(5 \times 10^{6}\right)$ and spleen cells $(10 \times$ $10^{6}$ ). To avoid bias from cage-related effects, animals were randomized before and after BMT as described (29).

IL-12 administration. Murine recombinant IL-12 (provided by Genetics Institute, Cambridge, MA), with a specific activity of 4.9-5.5 $\times$ $10^{6} \mathrm{U} / \mathrm{mg}$, was injected intraperitoneally into recipient mice $(2,500$ $\mathrm{IU} /$ mouse) in a single injection $\sim 1 \mathrm{~h}$ before BMT.

FCM analysis of donor $T$ cell expansion and activation. Recipient mice were killed at varying times after BMT, and single-cell suspensions of spleen cells were prepared. Cells were stained for $30 \mathrm{~min}$ at $4^{\circ} \mathrm{C}$ with FITC-conjugated $\mathrm{mAb}$ specific for activation markers (antiCD69 mAb H1.2F3 [PharMingen, San Diego, CA], anti-CD25 mAb 7D4 [PharMingen], and anti-very late activation [VLA] $4 \mathrm{mAb}$ [CoulterImmunotech, Palo Alto, CA]), PE-labeled anti-CD4 mAb (RM4-5; PharMingen) or anti-CD8 mAb (53-6.7; PharMingen), plus biotinylated antihost (B6) $\mathrm{H}-2 \mathrm{~K}^{\mathrm{b}} \mathrm{mAb} 5 \mathrm{~F} 1$, followed by incubation with $\mathrm{Cy}-$ Chrome-streptavidin (PharMingen) for $15 \mathrm{~min}$ at $4^{\circ} \mathrm{C}$. FITC-labeled and biotinylated mouse IgG2a mAb HOPC-1 and PE-labeled rat IgG2a mAb (PharMingen) were used as nonstaining negative control antibodies. To block nonspecific Fc $\gamma \mathrm{R}$ binding of labeled antibodies, $10 \mu \mathrm{l}$ of undiluted culture supernatant of $2.4 \mathrm{G} 2$ (rat anti-mouse Fc $\gamma \mathrm{R}$ $\mathrm{mAb}$; reference 30 ) was added to the first incubation. Cells were washed with FCM buffer (HBSS containing $0.1 \%$ BSA and $0.1 \%$ $\mathrm{NaN}_{3}$ ) between each and after the last stain, and were analyzed on a FACScan ${ }^{\circledR}$ (Becton Dickinson, Mountain View, CA).

Limiting dilution analysis. For measurement of host-reactive Th frequencies, varying numbers of responder cells (recipient spleen cells) were incubated with $6 \times 10^{5} 30 \mathrm{~Gy}$-irradiated B6 spleen stimulator cells. Responder cells were serially diluted (six threefold dilutions) and 24 wells were prepared for each dilution $(30,000,10,000$, $3,333,1,111,370$, or 123 responder cells/well). After $24 \mathrm{~h}$ of incubation, $100 \mu \mathrm{l}$ of supernatant were harvested from each well and added to parallel plates containing 8,000 IL-2-/IL-4-dependent cytotoxic T lymphocyte (CTL)L cells/well. The CTLL cells were incubated in the supernatants for $24 \mathrm{~h} ; 1 \mu \mathrm{Ci}$ of $\left[{ }^{3} \mathrm{H}\right]$ thymidine was then added to each well. After an additional $18 \mathrm{~h}$, cells were harvested and $\left[{ }^{3} \mathrm{H}\right]$ thymidine uptake was counted on a Betaplate $\beta$ counter (Wallac, Gaithersburg, $\mathrm{MD})$. Wells were considered as positive if $\left[{ }^{3} \mathrm{H}\right]$ thymidine uptake was three standard deviations greater than the mean $\left[{ }^{3} \mathrm{H}\right]$ thymidine uptake in 24 wells containing supernatants from stimulator cells alone. The Poisson distribution was used to determine the frequency of host antigen-responsive Th, and statistical analysis was performed by chi square minimization analysis as described by Taswell (31).

Statistical analysis. Statistical analysis of survival data was performed with the log rank test. Student's $t$ test was used to determine the level of significance of differences in group means. A $P$ value of $<0.05$ was considered to be significant in both types of analyses.

\section{Results}

Lethal acute GVHD can be induced in the absence of IFN- $\gamma$. To compare the development of acute lethal GVHD in the presence and absence of IFN- $\gamma$, WT or GKO B6 mice were lethally irradiated $(9.75 \mathrm{~Gy})$ and reconstituted with $5 \times 10^{6} \mathrm{TCD}$ syngeneic BMC plus allogeneic BMC $\left(7.5 \times 10^{6}\right)$ and spleen cells $\left(20 \times 10^{6}\right)$ from WT or GKO BALB/c mice. Lethally irradiated WT or GKO B6 mice injected with $5 \times 10^{6}$ TCD syngeneic BMC alone served as controls. Survival is shown in Fig. 1. The GKO B6 recipients of WT BMT (WT $\rightarrow$ GKO) showed survival curves similar to those of WT B6 recipients injected with WT inocula (WT $\rightarrow$ WT), demonstrating that host-derived IFN- $\gamma$ has no significant effect on the onset of acute GVHD (Fig. 1). Fig. 1 also shows that GKO BALB/c T cells were capable of inducing lethal acute GVHD after injection into lethally irradiated B6 mice. In WT $\rightarrow$ WT BMT recipients, the majority of GVHD-related deaths occurred before day 10 after BMT (median survival time $[\mathrm{MST}]=8 \mathrm{~d}$ ). Mortality was slightly delayed $(P<0.05)$ in WT recipients of GKO BALB/c inocula $(\mathrm{GKO} \rightarrow \mathrm{WT})$, with $>80 \%$ of animals succumbing between 10 and $14 \mathrm{~d}$ after BMT (MST $=12 \mathrm{~d}$; Fig. $1 A$ ). A similar trend was observed in GKO B6 recipients of GKO BMT $(\mathrm{GKO} \rightarrow \mathrm{GKO}$; MST $=12 \mathrm{~d})$ compared to GKO B6 mice receiving WT BMT (MST $=8 \mathrm{~d})$, but this difference was not statistically significant $(P=0.7$; Fig. $1 B)$. No difference in survival rates was observed between WT and GKO B6 recipients of GKO BMT, and all animals succumbed by $14 \mathrm{~d}$ after BMT (Fig. 1). These results demonstrate that, while IFN- $\gamma$ may increase the rate of early GVHD mortality, rapidly lethal acute GVHD can occur in the complete absence of IFN- $\gamma$.

IL-12-mediated protective effect against GVHD is dependent on donor-derived IFN- $\gamma$. Previous studies have shown that a single injection of IL-12 on the day of BMT prevents acute GVHD mortality in the $\mathrm{A} / \mathrm{J} \rightarrow \mathrm{B} 10$ (or B6) fully MHC plus multiple minor antigen-mismatched strain combination, and in the $\mathrm{CBD} 2 \mathrm{~F} 1 \rightarrow \mathrm{B} 6 \mathrm{D} 2 \mathrm{~F} 1$ full haplotype-mismatched strain combination (8-10). To evaluate the role of donor- and hostderived IFN- $\gamma$ in IL-12-induced GVHD protection, we made use of BALB/c and B6 WT and GKO mice. As we have ob-

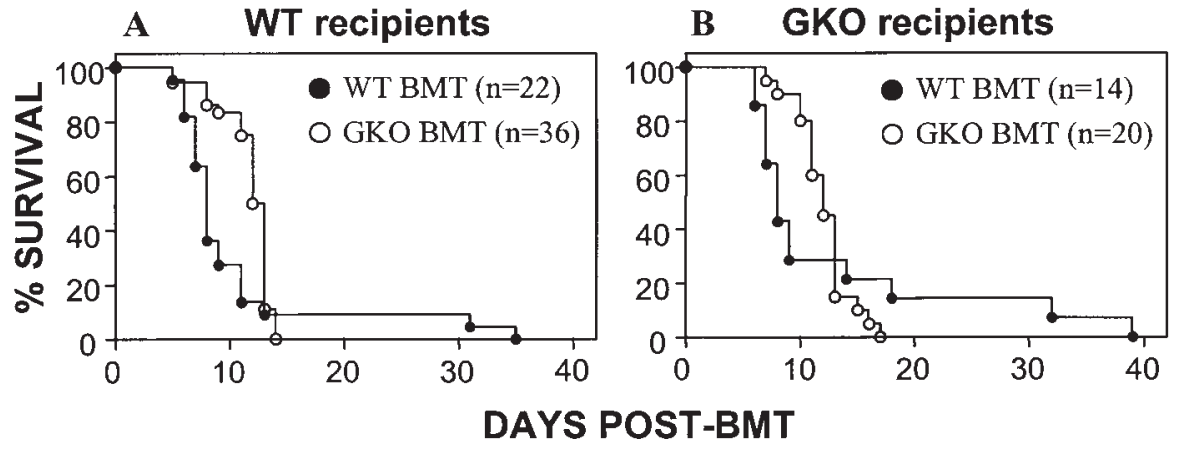

Figure 1. Induction of lethal acute GVHD in the presence and the absence of IFN- $\gamma$. Data from three experiments that gave similar results are combined. Survival is shown for lethally irradiated WT $(A)$ or GKO $(B)$ B6 recipients of allogeneic BMC and spleen cells from WT (filled circle) or GKO (open circle) BALB/c mice. Lethally irradiated recipients of TCD syngeneic BMC served as controls (at least six mice for each combination), and no death was seen in these animals (data not shown). 

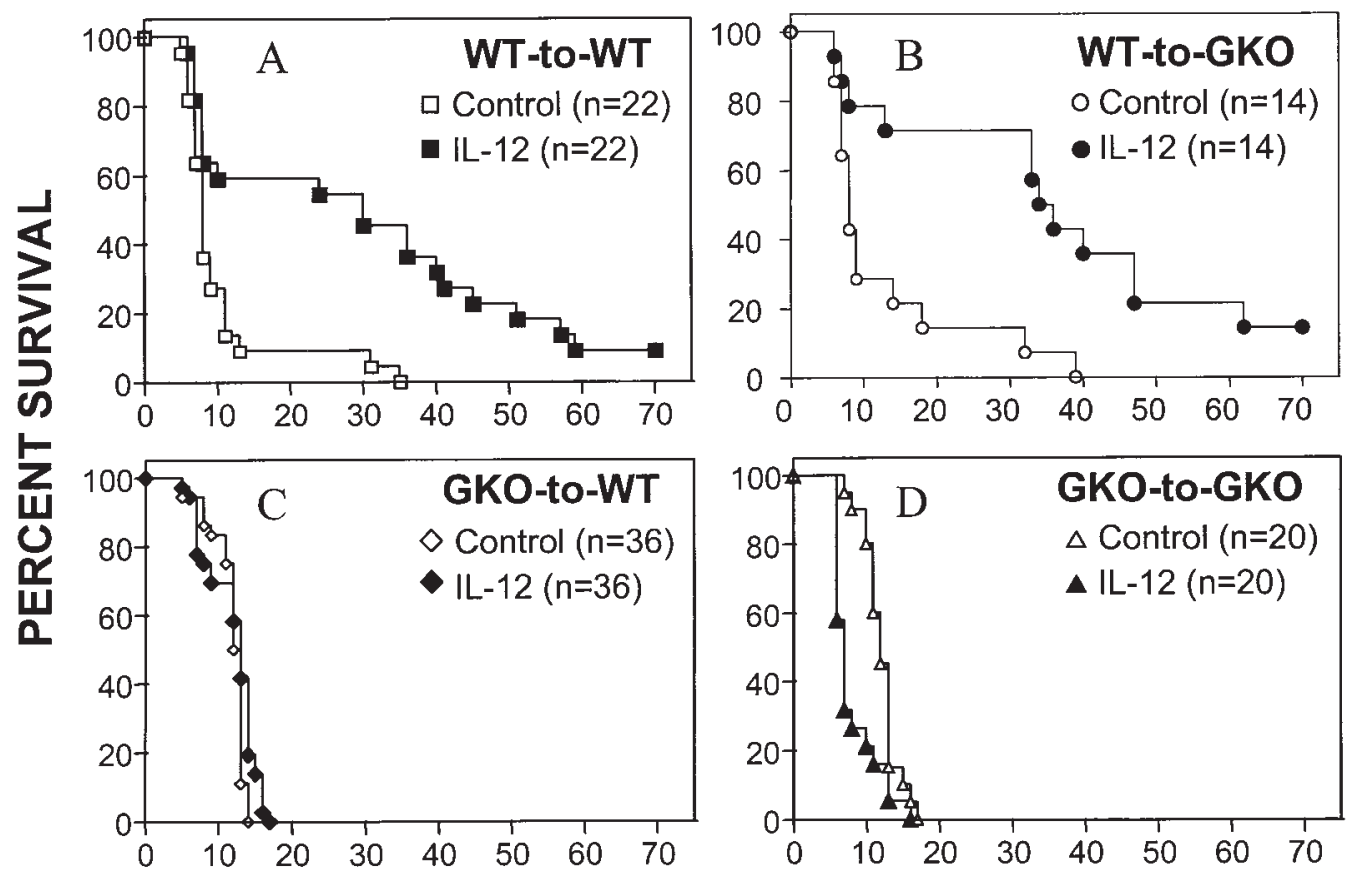

Figure 2. Requirement for donor-derived IFN- $\gamma$ in IL12-mediated GVHD protection. Survival is shown for lethally irradiated WT or GKO B6 recipients of allogeneic BMC and spleen cells from WT or GKO BALB/c mice with no further treatment or with IL-12 treatment. Data from three experiments that gave similar results are combined. The non-IL-12treated control groups are the same mice as those shown in Fig. 1 because the effect of IL-12 against GVHD was examined in the same experiments. Survival data of the control groups are presented again in this figure for the sake of clarity. IL-12 significantly prolonged the survival rate in recipients of WT but not GKO BALB/c DAYS POST-BMT cells.

served in other strain combinations, a single injection of IL-12, administered on the day of BMT, induced marked protection against GVHD in the WT BALB/c $\rightarrow$ B6 strain combination (Fig. 2 A). Survival in both WT and GKO B6 recipients of WT $\mathrm{BALB} / \mathrm{c}$ cells $(\mathrm{WT} \rightarrow \mathrm{WT}$ and $\mathrm{WT} \rightarrow \mathrm{GKO})$ was significantly prolonged, and to a similar extent, by treatment with IL-12 $(P<$ 0.001 compared to the control group without IL-12; Fig. 2, $A$ and $B)$. However, IL-12 had no effect on GVHD induced by GKO BALB/c cells in WT B6 recipients (Fig. $2 C ; P=0.3$ ). Furthermore, IL-12 significantly accelerated GVHD mortality in GKO B6 recipients of GKO BALB/c BMT $(\mathrm{MST}=7 ; P<$ 0.005 ) as compared to untreated controls (MST $=12 \mathrm{~d}$; Fig. 2 $D)$. Therefore, the inhibitory effect of IL-12 on the development of lethal acute GVHD was dependent on donor-derived IFN- $\gamma$, and in the complete absence of IFN- $\gamma(\mathrm{GKO} \rightarrow \mathrm{GKO})$, IL-12 significantly accelerated GVHD mortality. Apparently, host-derived IFN- $\gamma$ overcame the ability of IL-12 to accelerate
GVHD mortality in WT recipients of GKO BMT. However, the comparable level of protection induced by IL-12 in WT and GKO B6 recipients of WT BMT indicates that hostderived IFN- $\gamma$ was not required for IL-12 to mediate a protective effect against GVHD (Fig. 2).

Differential effect of IL-12 on the expansion and activation of allogeneic donor T cells from WT and GKO mice. Previous studies in the $\mathrm{A} / \mathrm{J} \rightarrow \mathrm{B} 6 \mathrm{BMT}$ model, in which the early development of acute GVHD is dependent on donor $\mathrm{CD}^{+}$cells (28), have shown that IL-12-mediated GVHD protection is associated with inhibition of the expansion and activation of donor Th cells that is evident in GVHD controls on days 4 and/or 5 after BMT (11). As shown in Fig. 3, the induction of acute GVHD in the BALB/c $\rightarrow$ B6 strain combination is also largely dependent on donor $\mathrm{CD}^{+}$cells. Lethally irradiated $\mathrm{B} 6$ mice receiving $\mathrm{BALB} / \mathrm{c} \mathrm{BMC}\left(5 \times 10^{6}\right)$ and spleen cells $\left(10 \times 10^{6}\right)$, from which $\mathrm{CD}^{+}$cells were depleted before BMT by anti-

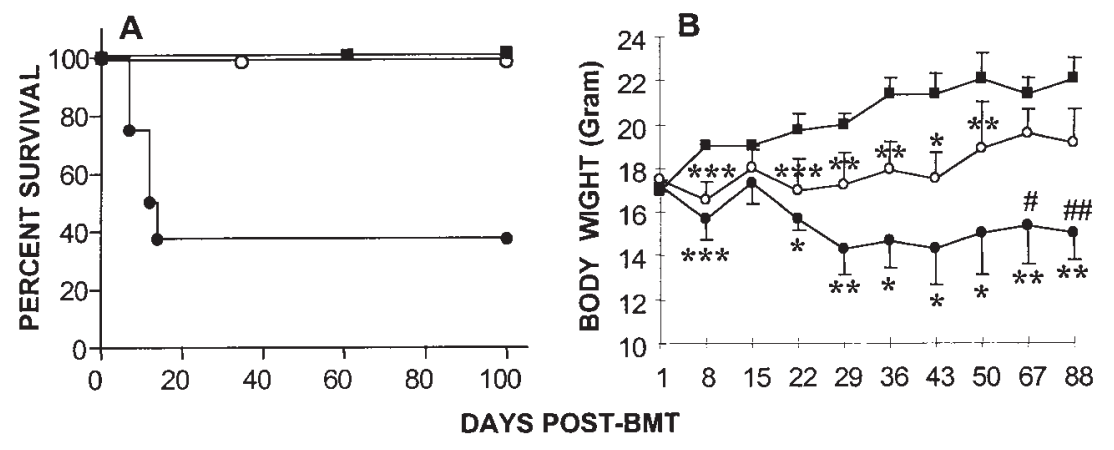

Figure 3. Contribution of donor $\mathrm{CD} 4^{+}$and $\mathrm{CD} 8^{+}$ cells to acute GVHD in the BALB/c $\rightarrow$ B6 strain combination. Survival $(A)$ and survivor body weights (group mean $\pm \mathrm{SD} ; B$ ) are shown for lethally irradiated WT B6 recipients of TCD syngeneic BMC (filled square; $n=3$ ), or TCD B6 BMC plus complement-treated BALB/c BMC and spleen cells (filled circle; $n=8$ ), or TCD B6 BMC plus CD4-depleted BALB/c BMC and spleen cells (open circle $n=8$ ). $* P<0.05, * * P<0.01$, $* * * P<0.005$ for the indicated group compared to the group receiving TCD syngeneic BMC only at the same time point. ${ }^{\#} P<0.05,{ }^{\# \#} P<0.005$ for the group receiving complement-treated allogeneic BMT compared to recipients of CD4-depleted allogeneic BMT. 
CD4 mAb plus complement, showed no GVHD mortality by $100 \mathrm{~d}$ after BMT. In contrast, $>60 \%$ of control B 6 recipients of complement-treated BALB/c BMC $\left(5 \times 10^{6}\right)$ and spleen cells $\left(10 \times 10^{6}\right)$ died of GVHD by $14 \mathrm{~d}$ after BMT (Fig. $\left.3 \mathrm{~A}\right)$. However, marked weight loss was observed in $\mathrm{B} 6$ recipients of CD4-depleted inocula as early as day 8 after BMT, indicating that $\mathrm{CD}^{+}$cells induced a milder form of acute GVHD (Fig. 3 $B)$. These results demonstrate that both $\mathrm{CD}^{+}$and $\mathrm{CD}^{+}$cells are involved in GVHD induction, but that donor $\mathrm{CD}^{+}$cells are critical in causing acute GVHD mortality in this strain combination.

Based on these observations and on our previous studies in the $\mathrm{A} / \mathrm{J} \rightarrow \mathrm{B} 6$ model, we hypothesized that the differential effect of IL-12 on the development of lethal acute GVHD induced by WT and GKO donor cells might reflect differences in the effect of IL-12 on the expansion and activation of donor $\mathrm{CD} 4{ }^{+}$cells from WT and GKO mice. To determine whether or not donor-derived IFN- $\gamma$ was required for this effect of IL-12, WT B6 recipient mice were killed on days 4, 5, 7, and 10 after BMT, and the expansion and activation of donor T cells was compared in IL-12-treated and untreated control recipients of WT or GKO BALB/c cells. Expression of CD69 and CD25, which is expressed early and transiently by activated $\mathrm{T}$ cells, and VLA4, a late activation marker, were studied in threecolor flow cytometric analyses. IL-12 treatment led to marked reductions in the number of total donor $\mathrm{CD} 4^{+}$cells and in the number of activated donor $\mathrm{CD}^{+}$cells $\left(\mathrm{CD} 69^{+} \mathrm{CD} 4^{+}\right.$,
$\mathrm{CD} 25^{+} \mathrm{CD} 4^{+}, \mathrm{VLA}_{4}{ }^{+} \mathrm{CD} 4^{+}$) in spleens of WT BALB/c $\rightarrow \mathrm{WT}$ B6 recipients on days 4 and 5 after BMT compared to untreated GVHD controls (Fig. 4, top). By day 7, the numbers of donor $\mathrm{CD}^{+}$cells had declined in spleens of GVHD controls, and no difference was observed between IL-12-treated mice and GVHD controls in the total numbers or in numbers of activated donor $\mathrm{CD}^{+}$cells.

Different kinetics of donor $\mathrm{CD}^{+}$cell expansion and activation were observed in untreated recipients of GKO BMT compared to untreated recipients of WT BMT. The numbers of total and activated donor $\mathrm{CD}^{+}$cells in spleens of $\mathrm{GKO} \rightarrow \mathrm{WT}$ BMT recipients were highest on day 4 and declined thereafter, whereas in $\mathrm{WT} \rightarrow \mathrm{WT}$ BMT recipients, these numbers were stable or increased between days 4 and 5. With the exception of $\mathrm{CD} 9^{+} \mathrm{CD} 4^{+}$cells, which were significantly higher in spleens of WT $\rightarrow$ WT BMT than GKO $\rightarrow$ WT BMT recipients at all time points studied, no significant difference was observed between the two groups in the numbers of total and activated donor $\mathrm{CD}^{+}$cells on day 4 after BMT. However, the numbers of these cells became significantly higher in spleens of $\mathrm{WT} \rightarrow \mathrm{WT}$ BMT than $\mathrm{GKO} \rightarrow \mathrm{WT}$ BMT recipients on day 5 after BMT (Fig. 4).

The effects of IL-12 on donor $\mathrm{CD}^{+}$cell numbers were quite different in $\mathrm{GKO} \rightarrow \mathrm{WT}$ BMT recipients than in $\mathrm{WT} \rightarrow$ WT BMT recipients. In the GKO $\rightarrow$ WT BMT group, IL-12 treatment also led to significant reductions in the total numbers of donor $\mathrm{CD}^{+}$cells in the spleen compared to controls
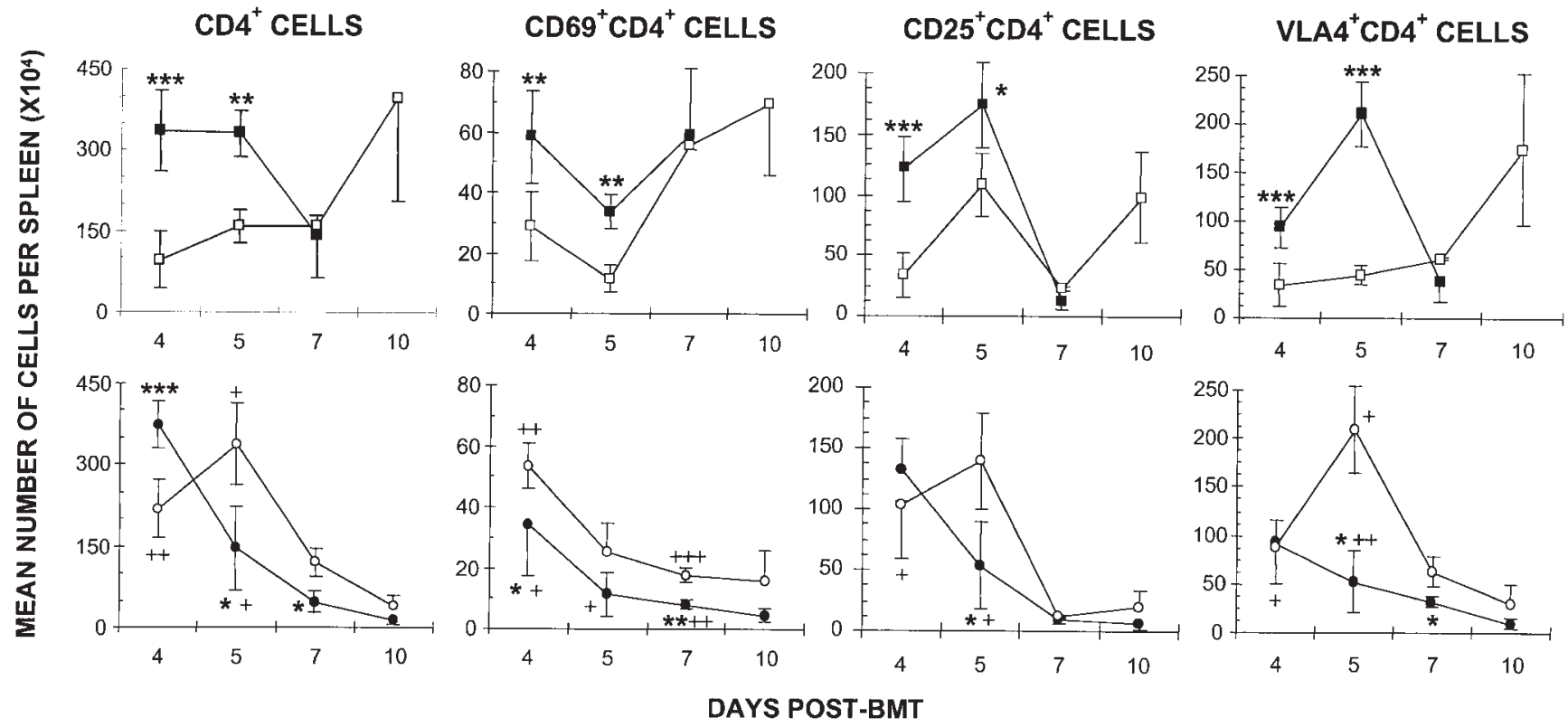

Figure 4. Comparison of donor CD4 T cell expansion and activation in IL-12-treated and control recipients of WT or GKO BMT. Spleen cells were prepared from WT BALB/c $\rightarrow$ WT B6 recipients with no further treatment (filled square) or with IL-12 treatment (open square), or from GKO BALB/c $\rightarrow$ WT B6 recipients with no further treatment (filled circle) or with IL-12 treatment (open circle), on days 4, 5, 7, and 10 after BMT. Since the donors are $\mathrm{H}-2 \mathrm{~K}^{\mathrm{d}+}$ and the recipients are $\mathrm{H}-2 \mathrm{~K}^{\mathrm{b}+}$, T cells that were not stained by anti-H- $2 \mathrm{~K}^{\mathrm{b}} \mathrm{mAb} 5 \mathrm{~F} 1$ were of donor origin. The number of donor $\mathrm{CD}^{+}$cells in recipient spleens was calculated as the product of the total number of spleen cells and the percentage of donor $\mathrm{CD} 4^{+}$cells as measured by FCM analysis $\left(5 \mathrm{~F} 1^{-} \mathrm{CD} 4^{+}\right)$. The number of activated donor $\mathrm{CD} 4^{+}$cells was calculated as the product of the total number of spleen cells and the percentage of donor $\mathrm{CD}^{+}$cells that expressed these activation makers as measured by FCM analysis $\left(5 \mathrm{~F} 1^{-} \mathrm{CD} 69^{+} \mathrm{CD} 4^{+}, 5 \mathrm{~F} 1^{-} \mathrm{CD} 25^{+} \mathrm{CD} 4^{+}\right.$, or $\left.5 \mathrm{~F} 1^{-} \mathrm{VLA} 4^{+} \mathrm{CD} 4^{+}\right)$. Each group includes three to seven animals at each time point, and data are presented as group means $( \pm \mathrm{SD}) . * P<0.05, * * P<0.01, * * * P<0.005$ for the indicated control group compared to the IL-12-treated group receiving the same BMT inoculum. ${ }^{+} P<0.05,{ }^{++} P<0.01,{ }^{++} P<0.005$ for GKO $\rightarrow$ WT BMT recipients compared to similarly treated recipients of WT BMT. 
on day 4 after BMT $(P<0.005$; Fig. 4 , bottom left $)$. However, the numbers of donor $\mathrm{CD} 4^{+}$cells in the spleens of the IL-12treated $\mathrm{GKO} \rightarrow \mathrm{WT}$ BMT recipients were significantly greater than those in IL-12-treated WT B6 recipients of WT BALB/c BMC and spleen cells $(P<0.01)$. Furthermore, by day 5 , the total numbers of donor $\mathrm{CD} 4^{+}$cells were significantly higher in spleens of IL-12-treated mice than in those of control recipients of GKO inocula $(P<0.05$; Fig. 4 , bottom $)$. This increase was still apparent on day 7 after BMT $(P<0.05)$.

Although a slight reduction in the number of $\mathrm{CD} 25^{+} \mathrm{CD} 4^{+}$ donor T cells was seen in spleens of IL-12-treated $\mathrm{GKO} \rightarrow \mathrm{WT}$ B6 recipients as compared to untreated controls on day 4 after BMT, this difference did not reach statistical significance. In parallel with the increased number of donor $\mathrm{CD}^{+}$cells, significant increases in numbers of donor $\mathrm{CD} 25^{+} \mathrm{CD} 4^{+}$and $\mathrm{VLA} 4{ }^{+} \mathrm{CD} 4^{+}$cells were also observed in IL-12-treated recipients of GKO BMT as compared to untreated controls by day 5 (Fig. 4, bottom). In addition, the numbers of activated donor $\mathrm{CD}^{+}$cells were markedly higher in IL-12-treated GKO $\rightarrow$ WT recipients than in IL-12-treated WT $\rightarrow$ WT recipients on day 4 or days 4 and 5 after BMT (Fig. 4). Together, these results suggest that donor-derived IFN- $\gamma$ plays an important role in the inhibitory effects of IL-12 on the expansion and activation of donor $\mathrm{CD}^{+}$cells. At a later time point (day 10), after non-IL12-treated control recipients of WT inocula had succumbed to GVHD, greater numbers of total and activated donor CD4 ${ }^{+}$ cells were detected in spleens of IL-12-treated WT $\rightarrow$ WT recipients than were detected on day 7 (Fig. 4, top). These numbers were markedly reduced in IL-12-treated recipients of GKO BMC and spleen cells (Fig. 4, bottom).
The average numbers of total donor $\mathrm{CD}^{+}$cells and of activated donor $\mathrm{CD}^{+}$cells in spleens of untreated $\mathrm{GKO} \rightarrow \mathrm{WT}$ $\mathrm{BMT}$ recipients were higher than those in untreated $\mathrm{WT} \rightarrow \mathrm{WT}$ BMT recipients on days 4 and/or 5 after BMT, but these differences were not statistically significant. In recipients of WT BMT, IL-12 induced a similar delay in the expansion and activation of donor $\mathrm{CD}^{+}$cells to that observed for donor $\mathrm{CD}^{+}$ cells in comparison to GVHD controls (Fig. 5, top). However, IL-12 more efficiently delayed the proliferation and activation of $\mathrm{GKO}$ donor $\mathrm{CD}^{+}$cells (Fig. 5, bottom) than of $\mathrm{CD}^{+}$cells from the same donors (Fig. 4, bottom). A significant reduction in numbers of $\mathrm{CD}^{+}, \mathrm{CD} 9^{+} \mathrm{CD} 8^{+}, \mathrm{CD} 25^{+} \mathrm{CD} 8^{+}$, and $\mathrm{VLA} 4{ }^{+} \mathrm{CD}^{+}$donor cells was observed in IL-12-treated compared to control recipients of GKO BMT on days 4 and/ or 5 after BMT. By day 7, the numbers of donor $\mathrm{CD}^{+}$, $\mathrm{CD} 25^{+} \mathrm{CD} 8^{+}$, and $\mathrm{VLA} 4{ }^{+} \mathrm{CD} 8^{+}$cells became higher in spleens of IL-12-treated than control recipients of GKO BMT $(P<$ $0.05)$. In addition, the numbers of total and activated donor $\mathrm{CD}^{+}$cells were greater on days 4 and 5 in IL-12-treated recipients of GKO BMT than in similarly-treated recipients of WT BMT (Fig. 5). Thus, the magnitude of IL-12-mediated inhibition of the expansion and activation of GKO donor $\mathrm{CD}^{+}$ cells was less marked than its effect on WT donor $\mathrm{CD}^{+}$cells. Since donor $\mathrm{CD}^{+}$cells are critical for the induction of acute GVHD in this strain combination (Fig. 3), reduced expansion and activation of donor $\mathrm{CD}^{+}$cells alone by IL-12 in recipients of GKO BMT failed to mediate a protective effect against GVHD (Fig. 2). Similar to $\mathrm{CD}^{+}$cells, a later expansion (day 10 after BMT) of donor $\mathrm{CD}^{+} \mathrm{T}$ cells was observed in spleens of IL-12-treated recipients of WT BALB/c BMC and spleen
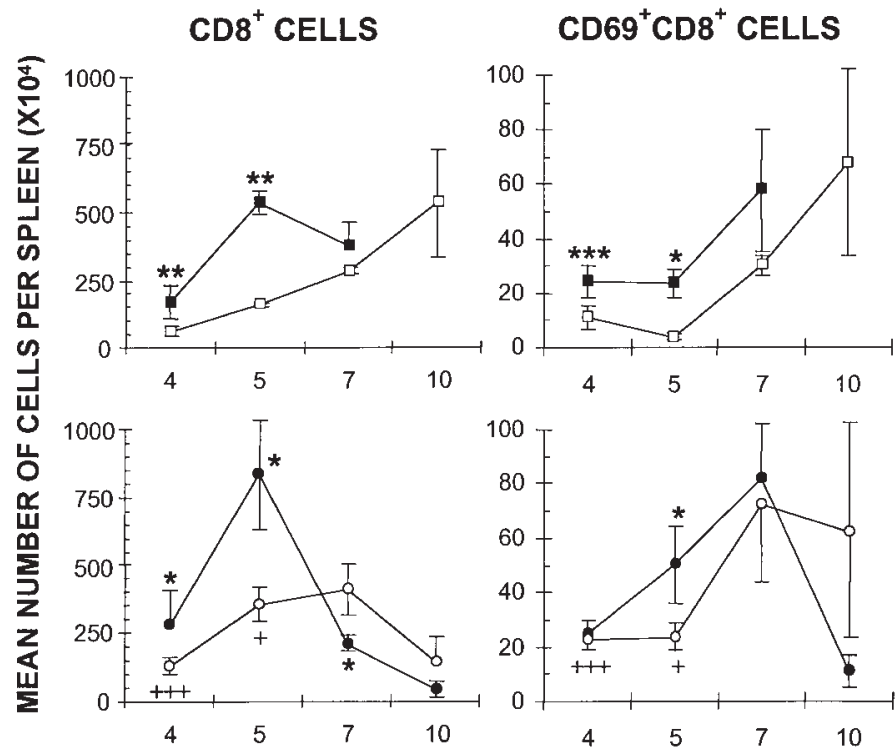

CD25 ${ }^{+} \mathrm{CD} 8^{+}$CELLS
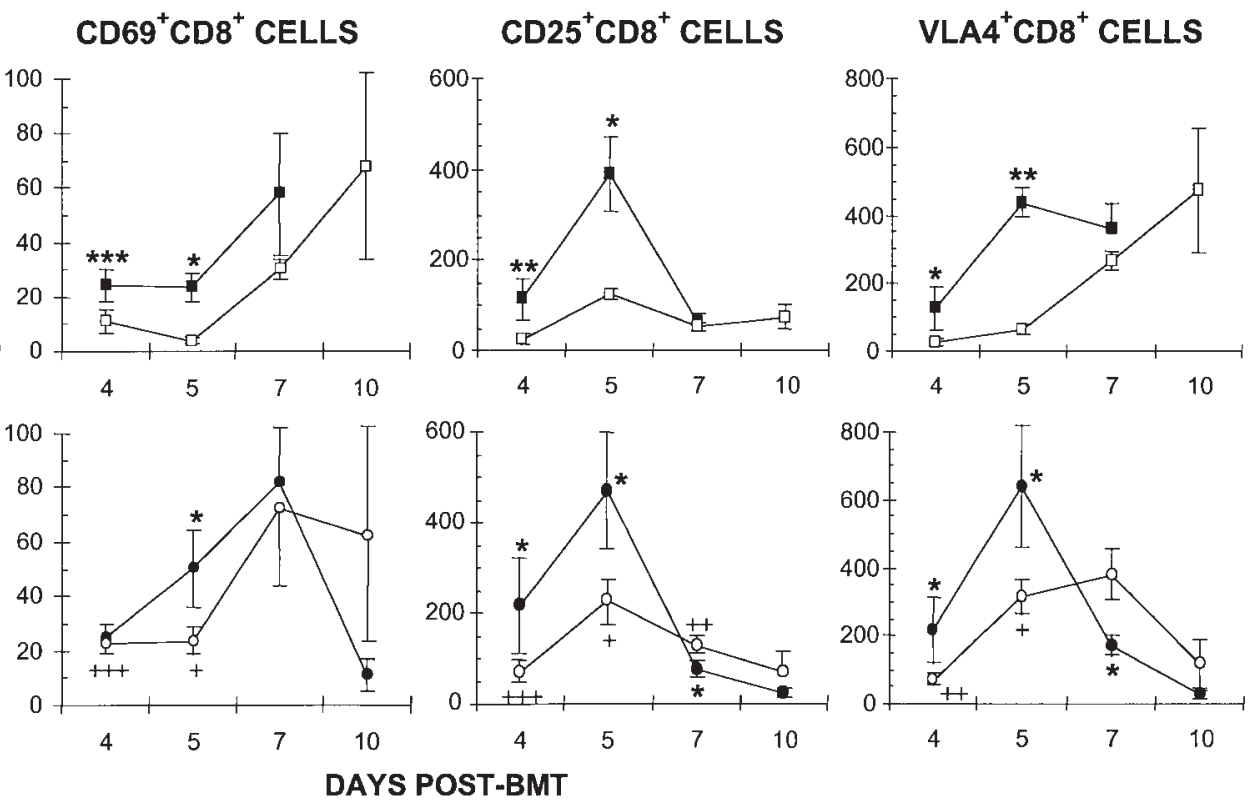

Figure 5. Comparison of donor CD8 T cell expansion and activation in IL-12-treated and control recipients of WT or GKO BMT. Spleen cells were prepared from WT BALB/c $\rightarrow$ WT B6 recipients with no further treatment (filled square), with IL-12 treatment (open square), or from GKO BALB/c $\rightarrow$ WT B6 recipients with no further treatment (filled circle) or with IL-12 treatment (open circle), on days 4, 5, 7, and 10 after BMT. The results were obtained from the same experiment shown in Fig. 4. The numbers of total donor CD8 ${ }^{+}$cells and of activated donor $\mathrm{CD}^{+}$cells in recipient spleen were calculated in a similar manner as that for donor CD4 ${ }^{+}$cells, as described in the legend of Fig. 4. Each group includes three to seven animals at each time point, and data are presented as group means $( \pm \mathrm{SD})$. $* P<0.05$, ** $P<0.01$, *** $P<0.005$ for the indicated control group compared to the IL-12-treated group receiving same BMT inoculum. ${ }^{+} P<0.05,{ }^{++} P<0.01,{ }^{+++} P<0.005$ for $\mathrm{GKO} \rightarrow$ WT BMT recipients compared to similarly treated recipients of WT BMT. 
Table I. IL-12 Reduces Activated Host-reactive Th Numbers in the Spleens of WT BALB/c $\rightarrow B 6$, but Not GKO

$B A L B / c \rightarrow B 6$ Recipients

\begin{tabular}{lccc}
\hline \multirow{2}{*}{ Groups } & \multicolumn{3}{c}{$\begin{array}{c}\text { Numbers of host-reactive Th cells per spleen } \\
\text { of BMT recipients }(\times 1,000)^{*}\end{array}$} \\
\cline { 2 - 4 } & Day 4 & Day 5 & Day 10 \\
\hline $\mathrm{WT} \rightarrow \mathrm{WT}$ & $33.7 \pm 8.6$ & $>120.2 \pm 10.2^{\text {qा }}$ & ND \\
$\mathrm{WT} \rightarrow \mathrm{WT}+\mathrm{IL}-12$ & $0.4 \pm 0.3^{\ddagger}$ & $13.2 \pm 2.3^{\S \|}$ & $24.8 \pm 3.9^{\|}$ \\
$\mathrm{GKO} \rightarrow \mathrm{WT}$ & $74.6 \pm 16.9$ & $62.3 \pm 32.4$ & $7.7 \pm 2.8$ \\
$\mathrm{GKO} \rightarrow \mathrm{WT}+\mathrm{IL}-12$ & $2.9 \pm 1.4^{\ddagger}$ & $>88 \pm 31.8^{\sharp}$ & $10.1 \pm 4$
\end{tabular}

*The total number of host-reactive Th cells per spleen was determined by the product of the Th frequency and the total number of spleen cells harvested from each individual animal, and data are presented as group means \pm SD. Each group contains three animals at each time point. The total numbers of host-reactive Th cells in the spleens of naive BALB/c mice were $5.8 \pm 1.4\left(\times 10^{3}\right)(n=3)$. ND, not done. ${ }^{\ddagger} P<0.05,{ }^{\S} P<0.005$ for the indicated group compared to $\mathrm{B} 6$ recipients receiving similar BMT inocula without IL-12 treatment. $\| P<0.05$ for the indicated group $(W T \rightarrow W T+I L-12)$ compared to IL-12-treated recipients of GKO BMT $(G K O \rightarrow W T+I L-12)$. "The host-reactive Th frequencies of some or all samples in the indicated groups were higher than the countable range of the assay (i.e., $>1 / 123$ cells, the lowest cell concentration in this LDA assay), and the frequencies of these samples were calculated as $>1 / 123$.

cells. Previous studies in another strain combination, in which the development of acute GVHD is also dependent on donor $\mathrm{CD}^{+} \mathrm{T}$ cells, have shown that $\mathrm{CD} 8^{+} \mathrm{T}$ cell-mediated antihost CTL activity is extremely low in GVHD controls, and is unaffected by IL-12 treatment (11). Consistently, the expanded donor $\mathrm{CD}^{+} \mathrm{T}$ cells detected in spleens of IL-12-treated recipients of WT BALB/c BMT on day 10 showed no antihost CTL activity, as measured by LDA (data not shown).

IL-12 inhibits antihost Th responses of allogeneic WT Th cells, but not of GKO Th cells. LDA was used to compare the frequencies of activated host-reactive Th cells in control and IL-12-treated recipients of WT and GKO BMT. Similar to results we have obtained in another strain combination (11), a very high frequency of host-reactive activated Th cells was detected in spleens of GVHD controls. The total numbers of host-reactive Th cells per recipient spleen were markedly reduced in IL-12-treated recipients of WT BMT compared to controls on days 4 and 5 (Table I), similar to our previous results in a different strain combination (11). Despite a subsequent increase in the number of donor $\mathrm{CD}^{+}$cells observed in spleens of IL-12-protected mice on day 10 after BMT (Fig. 4, top), these cells showed weaker antihost responses than those of non-IL-12-treated controls on days 4 and 5 (Table I). Since most untreated WT BALB/c $\rightarrow$ WT B6 recipients succumbed to GVHD by day 10 after BMT, no data were obtained at day 10 from these mice.

The kinetics of the antihost Th response were quite different in recipients of GKO BMT compared to recipients of WT BMT. Although these responses increased between days 4 and 5 in the latter group, antihost Th responses were highest at day 4 in recipients of GKO BMT, at which time they were greater than the responses in recipients of WT BMT. The antihost Th response declined thereafter in recipients of GKO BMT. These differing kinetics of antihost Th expansion and/or acti- vation were reflected in the kinetics of $\mathrm{CD} 4^{+}$cell numbers, as well as numbers of $\mathrm{CD} 4^{+} \mathrm{CD} 25^{+}$and $\mathrm{CD} 4^{+} \mathrm{VLA} 4^{+}$cells in the spleens of the two groups (Fig. 4).

Consistent with the results in Fig. 4 (bottom) showing that IL-12 treatment led to a reduction in the total number and the number of activated donor $\mathrm{CD} 4^{+}$cells on day 4 in recipients of GKO BMT, a reduction in antihost-activated Th was observed in IL-12-treated compared to control recipients of GKO BMT at this time (Table I). However, the levels of host-reactive Th cells in the spleens of these mice increased significantly by day 5 , becoming higher than those in untreated control recipients, and markedly greater than those in IL-12-protected recipients of WT BMT $(P<0.05$, Table I). By day 10 after BMT, perhaps due to activation-induced cell death or to the trafficking of donor T cells into GVHD target tissues, the number of hostreactive Th cells had declined significantly in both untreated and IL-12-treated recipients of GKO BMT, and was not different between the two groups (Table I). The kinetics of hostreactive Th responses in both control and IL-12-treated recipients of GKO BMT showed a correlation with the numbers of total and activated donor $\mathrm{CD}^{+}$cells (Fig. 4). Overall, our results demonstrate that IL-12 has a lesser inhibitory effect on GVHD-associated host-reactive Th activation and expansion in recipients of GKO BMT compared to recipients of WT BMT. Thus, donor-derived IFN- $\gamma$ is required for maximal inhibition of antihost Th responses in IL-12-treated allogeneic BMT recipients.

IFN- $\gamma$-independent inhibitory effect of IL-12 on antihost responses of donor $T$ cells. Despite the lesser extent to which IL-12 altered donor T cell expansion and activation in recipients of GKO compared to WT BMT, the recipients of GKO BMT nevertheless showed some degree of inhibition with IL12 treatment (Figs. 4 and 5, and Table I). This inhibition was most apparent at day 4 after BMT. To determine whether IL12-induced inhibition of donor T cells in WT B6 recipients of GKO BMT might be mediated by host-derived IFN- $\gamma$, we repeated this study in the GKO BALB/c $\rightarrow$ GKO B6 combination. Again, a significant reduction in the total numbers of $\mathrm{T}$ cells, in the numbers of activated donor $\mathrm{CD}^{+}$and $\mathrm{CD}^{+}$cells (Fig. 6), and in the levels of activated host-reactive Th cells (Table II) was observed in IL-12-treated compared to control mice on day 4 after BMT. Because both recipients and donors in this study were deficient in IFN- $\gamma$ production, these results demonstrate that IL-12 can inhibit the early expansion and activation of donor $\mathrm{T}$ cells and host-reactive Th activities in the complete absence of IFN- $\gamma$. However, this early inhibitory effect of IL-12 on donor T cells by day 4 after BMT was not associated with a reduction in GVHD-induced mortality, as GVHD mortality was similar in IL-12-treated and control WT recipients of GKO BMT (Fig. $2 C$ ), and was even accelerated in IL-12-treated compared to untreated GKO recipients of GKO BMT (Fig. 2 D).

\section{Discussion}

The data presented here demonstrate that IL-12-induced protection against GVHD-associated mortality is dependent on IFN- $\gamma$ produced by allogeneic donor cells. IL-12 mediated significant protection from GVHD only when WT mice were used as allogeneic donors and not when GKO mice were used. Our previous studies in the $\mathrm{A} / \mathrm{J}$ to $\mathrm{B} 6$ strain combination have 

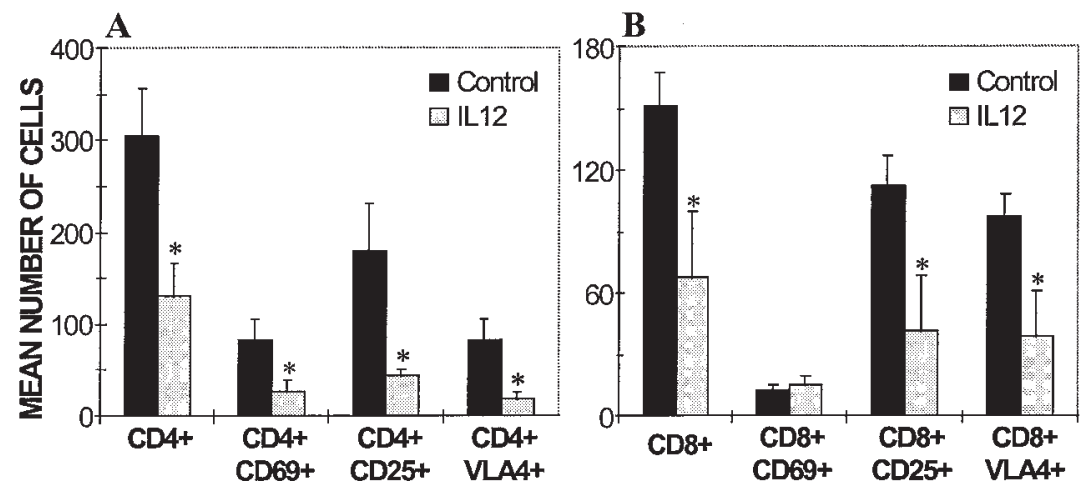

Figure 6. IL-12 induces early (day 4) inhibition of donor $\mathrm{T}$ cell expansion and activation via an IFN$\gamma$-independent mechanism. Spleen cells were prepared from $\mathrm{GKO} \mathrm{BALB} / \mathrm{c} \rightarrow \mathrm{GKO}$ B6 recipients with no further treatment or with IL-12 treatment on day 4 after BMT. The numbers of total and activated donor $\mathrm{CD}^{+}(A)$ and $\mathrm{CD}^{+}(B)$ cells in recipient spleen were calculated as described in the legends of Figs. 4 and 5, and data are presented as group means ( $n=3$ for each group). $* P<0.05$ compared to nontreated controls.

shown that the expansion and activation of donor T cells, especially of $\mathrm{CD}^{+}$cells on days 4 and/or 5 , is correlated with the rate of acute GVHD mortality, and that inhibition of this donor $\mathrm{T}$ cell expansion and activation is associated with the IL12-mediated protective effect against GVHD (11). Consistent with these results, this study demonstrated that donor-derived IFN- $\gamma$ is required for maximal inhibition of the expansion and activation of donor $\mathrm{CD}^{+}$cells (Fig. 4) and of antihost Th responses (Table I) in IL-12-treated BMT recipients. Although IL-12 treatment also reduced the expansion and activation of host-reactive donor T cells that occurred by day 4 after BMT via an IFN- $\gamma$-independent mechanism (Figs. 4-6, and Tables I and II), no clinically apparent inhibitory effect against GVHD was associated with IL-12 treatment in recipients of GKO BMT (Fig. 2). Importantly, by day 5, the total number, the number of activated donor $\mathrm{CD} 4^{+} \mathrm{T}$ cells, and the level of hostreactive Th cells in IL-12-treated recipients of GKO BMT increased to similar or higher levels than those in untreated controls (Fig. 4 and Table I). Thus, the failure of IL-12 to protect recipients of GKO BMT against GVHD is associated with early (by day 5) rebound of antihost CD4 responses in the absence of donor-derived IFN- $\gamma$. Consistent results were observed in the $\mathrm{A} / \mathrm{J} \rightarrow \mathrm{B} 6$ combination, in which administration of neutralizing anti-IFN- $\gamma \mathrm{mAb}(5 \mu \mathrm{g})$ into BMT recipients on day 1 after BMT markedly attenuated the inhibitory effect of IL-12 on donor $\mathrm{T}$ cell activation and expansion, and diminished the IL-12-mediated protective effect against GVHD (data not shown). These results demonstrate that IL-12, an immunostimulatory cytokine, can paradoxically inhibit the activation and expansion of alloreactive $\mathrm{T}$ cells, and that the maximal inhibitory effect is dependent on IFN- $\gamma$.

As is shown in Fig. 4 (top), the numbers of activated donor $\mathrm{CD}^{+} \mathrm{T}$ cells increased markedly in spleens of IL-12-treated $\mathrm{WT} \rightarrow \mathrm{WT}$ BMT recipients between days 7 and 10 after BMT.
This later increase may reflect antigen-driven donor $\mathrm{T}$ cell expansion that is delayed by IL-12, or may result from the retention of donor $\mathrm{T}$ cells in the spleen, perhaps due to a defect in trafficking to GVHD target tissues. In contrast to IL-12treated $\mathrm{WT} \rightarrow \mathrm{WT}$ BMT recipients, the numbers of activated donor $\mathrm{CD}^{+}{ }^{+} \mathrm{T}$ cells were very low in spleens of IL-12-treated and control GKO $\rightarrow$ WT recipients on day 10 (Fig. 4, bottom). Thus, it is likely that donor-derived IFN- $\gamma$ is required for the later increase in donor $\mathrm{T}$ cells in spleens of IL-12-treated $\mathrm{WT} \rightarrow \mathrm{WT}$ BMT recipients, raising the possibility that donorderived IFN- $\gamma$ might protect from GVHD by delaying donor T cell activation and/or by preventing the trafficking of donor $\mathrm{T}$ cells from spleen to GVHD target tissues. In addition, we do not know the basis for the discrepancy between the later (day 10) increase in donor $\mathrm{CD}^{+} \mathrm{T}$ cells observed in conjunction with the lower antihost responses of these cells in spleens of IL-12-treated WT $\rightarrow$ WT BMT recipients compared to those observed in controls on day 5 , when $\mathrm{T}$ cell numbers in the spleen were similar to those of IL-12-treated mice on day 10 (Fig. 4 and Table I). Because the proliferation of CTLL indicator cells used in our LDA assay is dependent on IL-2 or IL-4, the relatively low frequency of host-reactive Th cells in IL-12treated mice on day 10 could reflect a failure of activated $\mathrm{T}$ cells to produce these cytokines so that their antihost responses were not measurable. Perhaps these cells mature later to cause delayed GVHD mortality. However, a similar discrepancy has been observed in IL-12-treated BMT recipients in the $\mathrm{CBD} 2 \mathrm{~F} 1 \rightarrow \mathrm{B} 6 \mathrm{D} 2 \mathrm{~F} 1$ strain combination, in which IL-12 permanently prevents both acute and chronic GVHD (Yang, Y.-G., B. Dey, and M. Sykes, unpublished data; and reference 10). Thus, the activated $\mathrm{CD}^{+}{ }^{+} \mathrm{T}$ cells detected later in spleens of IL-12-treated mice may be relatively deficient in antihost effector function. Further studies will be needed to determine the reactivity and GVHD potential of these cells.

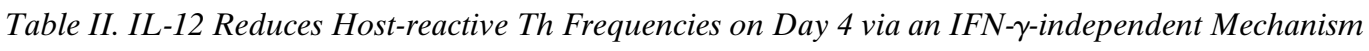

\begin{tabular}{ccccc}
\hline Groups & WT $\rightarrow$ GKO & WT $\rightarrow$ GKO + IL-12 & GKO $\rightarrow \mathrm{GKO}$ & GKO $\rightarrow \mathrm{GKO}+\mathrm{IL}-12$ \\
\hline No. Th per spleen $(\times 1,000)^{*}$ & $63.3 \pm 37.6$ & $3.7 \pm 0.6^{\ddagger}$ & $>79.7 \pm 13.5^{\S}$ & $14.1 \pm 5.3^{\ddagger}$ \\
\hline
\end{tabular}

*The total number of host-reactive Th cells per spleen was determined by the product of the Th frequency and the total number of spleen cells harvested from each individual animal, and data are presented as group means \pm SD. Each group contains three animals. The total number of hostreactive Th cells in the spleen of normal BALB/c mouse was $4.2 \pm 1.4\left(\times 10^{3}\right) .{ }^{\ddagger} P<0.05$ for the indicated group compared to B6 recipients receiving similar BMT inoculum without IL-12 treatment. ${ }^{\circledR}$ The host-reactive Th frequencies in the recipient spleens of indicated groups were higher than the countable range of the assay (i.e., $>1 / 123$ cells, the lowest cell concentration in this LDA assay), and the frequencies of these samples were calculated as $>1 / 123$. 
Although this study cannot rule out the possibility that host-derived IFN- $\gamma$ contributes to IL-12-mediated GVHD protection in other strain combinations, the data presented here indicate that host-derived IFN- $\gamma$ is not required for the protective effect of IL-12 against GVHD, and that hostderived IFN- $\gamma$ alone is unable to mediate the GVHD protective effect of IL-12 (Fig. 2). The lack of an inhibitory effect of IL-12 on GVHD in WT recipients of GKO BMT might be due to a failure of host-derived IFN- $\gamma$ to be produced in sufficient amounts. Although previous studies in the $\mathrm{A} / \mathrm{J} \rightarrow \mathrm{B} 10$ strain combination have shown that although in vivo depletion of host NK cells with anti-NK1.1 mAb PK136 reduced the early (day 2) rise in serum IFN- $\gamma$ levels usually observed in IL-12treated mice (8), this inhibition was incomplete and failed to abrogate IL-12 protection (our unpublished data). However, in the B10.A $\rightarrow$ B10 combination in which NK cells from both donor and host express NK1.1 and can be depleted by NK1.1specific mAb PK136, we observed that depletion of both donor and host NK cells markedly suppressed the IL-12-induced early increase in IFN- $\gamma$ production and abrogated IL-12-mediated GVHD protection (Dey, B., Y.-G. Yang, M. Sykes, manuscript in preparation). These results indicate that donor NK cells may play an important role in the IL-12-induced protective effect against GVHD. Consistent with a protective role for donor NK cells in the $\mathrm{BALB} / \mathrm{c} \rightarrow \mathrm{B} 6$ model used here, we have observed that the addition of WT BALB/c spleen cells to GKO BALB/c BMC/splenocyte inocula allows IL-12 to induce GVHD protection in WT B6 recipients. This protective effect is preserved when CD4, CD8, or both CD4 and CD8 T cells are depleted from WT spleen cell populations (data not shown).

IFN- $\gamma$ has been shown to play a critical role in the development of acute GVHD by activating macrophages to produce proinflammatory cytokines such as TNF- $\alpha$ and IL-1 (16-20, 32). Consequently, acute GVHD has been linked to the activation of alloreactive Th1 cells that produce IFN- $\gamma(33,34)$. However, not all studies support this simple Th1-Th2 paradigm in the pathogenesis of GVHD. For example, treatment with IL-10 led to inhibition of Th1 responses and IFN- $\gamma$ production in allogeneic BMT recipients, but had no protective effect against GVHD-associated weight loss and mortality (35). In addition, administration of exogenous IFN- $\gamma$ has been shown to markedly inhibit GVHD (21), and results from our own and others studies have shown that neutralizing IFN- $\gamma$ with $\mathrm{mAb}$ has no significant inhibitory effect on the development of acute GVHD $(9,36)$. A recent study in a parent $\rightarrow$ nonirradiated F1 BMT model, in which GKO mice were used as BMT donors and WT mice were used as recipients, has shown that lethal GVHD can be induced in the absence of donorderived IFN- $\gamma$ (37). However, the results from that study suggested that donor-derived IFN- $\gamma$ played a critical role in the induction of lethal acute GVHD, as most mice receiving GKO BMT died chronically between days 50 and 90 after BMT, whereas the recipients of WT BMT died 15 to $20 \mathrm{~d}$ after BMT (37). In this study, we show clearly that IFN- $\gamma$ is not critical for the induction of acute GVHD. The studies in GKO $\rightarrow \mathrm{GKO}$ BMT demonstrate that lethal acute GVHD can be induced in the complete absence of IFN- $\gamma$ (Fig. $2 D$ ).

Although IFN- $\gamma$ plays an important role in the induction of Th1 development by IL-12 (15), IL-12 has been shown to be capable of inducing the development of Th1 cells and suppressing Th2 development independently of IFN- $\gamma(15,38-$
40). Therefore, GKO T cells could develop toward either Th1 (at least with respect to IL-2 production) or Th2 cells after alloantigen stimulation. Although previous studies have suggested that Th1 cells play a critical role in the development of acute GVHD $(33,34)$, we have obtained results in signal transducer and activator of transcription factor (STAT)4- and STAT6-deficient mice suggesting that both Th1 and Th2 contribute to acute GVHD (our unpublished data). This study has not identified whether or not GKO and WT T cells induce GVHD via distinct mechanisms, or whether or not cytokine production patterns differ. Spleen cells from GKO mice have been shown to exhibit enhanced alloreactivity compared to WT cells in both mixed lymphocyte reaction (MLR) and CTL assays (41). Consistent with these observations, antihost Th responses were higher on day 4 in recipients of GKO BMT than in mice receiving WT BMT (Table I), and it is possible that peak responses may have occurred earlier than day 4. The kinetics of GVHD mortality (Fig. 1) and antihost responses of donor $\mathrm{CD}^{+}$cells (Fig. 4 and Table I) differed in recipients of WT and GKO BMT, suggesting that the pathogenesis of GVHD induced by WT and GKO donor T cells might be not identical. The differential effect of IL-12 on GVHD in the two groups might reflect the presence of distinct effector mechanisms in the presence and absence of IFN- $\gamma$.

Fas expression on donor $\mathrm{T}$ cells in allogeneic BMT recipients is increased by treatment with IL-12, and IL-12-induced GVHD protection is partly dependent on the expression of functional Fas molecules by the donor (11). Thus, donor T cell apoptosis is one of the likely mechanisms for IL-12-induced GVHD protection. IFN- $\gamma$ plays an important role in regulating the death of activated T lymphocytes (42-44). A recent study using a Th1 clone showed that the apoptosis of in vitro activated Th1 cells can be inhibited by neutralizing IFN- $\gamma$ with $\mathrm{mAb}$, and that anti-IFN- $\gamma$ mAb can block the upregulation of Fas ligand expression on activated Th1 cells (45). Recently, IFN- $\gamma$ has been shown to be required for induction of longterm allograft survival by $\mathrm{T}$ cell costimulation blockade, but this effect of IFN- $\gamma$ was Fas independent (46). IFN- $\gamma$ has been shown to make tumor cells susceptible to Fas-induced apoptosis $(47,48)$. Therefore, the role of IFN- $\gamma$ in IL-12-mediated GVHD protection may be to make host-reactive donor T cells susceptible to Fas-mediated cell death. The role of IFN- $\gamma$ in the IL-12-induced increase in Fas expression on donor CD4 T cells (11) and in the ability of IL-12 to induce apoptotic death of host-reactive donor T cells during GVHD induction is currently under investigation.

Overall, the data presented in this study demonstrate that donor-derived IFN- $\gamma$ is required for the protective effect of IL12 against GVHD, but that IFN- $\gamma$ is not required for the induction of lethal acute GVHD. In addition, our studies show that IL-12 can transiently inhibit GVH alloreactivity induced by an IFN- $\gamma$-independent pathway. Both IL-12 and IFN- $\gamma$ are important regulatory cytokines of immune responses and have antitumor effects of their own $(12,49-54)$. Unlike most available means of GVHD prophylaxis, which are associated with increased rates of allograft failure and leukemic relapse (5558), our previous studies showed that IL-12 can preserve graftversus-leukemia effects without compromising marrow engraftment while inhibiting GVHD in mice $(9,10)$. Thus, the use of IL-12 might have the potential to overcome GVHD and thereby facilitate the HLA-mismatched allogeneic BMT in leukemic patients. 


\section{Acknowledgments}

We thank Dr. Boris Nikolic and Ms. Jessica Sachs for helpful review of the manuscript and Dr. David H. Sachs for his advice and encouragement. We also thank Ms. Guiling Zhao for outstanding animal care and Ms. Diane Plemenos for expert secretarial assistance.

This work was supported by National Cancer Institute grant R01 64912 and American Cancer Society grant RPG-95-071-03-CIM. Dr. Yang was partially supported by the Massachusetts General Hospital Kaye award in Hematological Malignancies.

\section{References}

1. Manetti, R., P. Parronchi, M.G. Giudizi, M.-P. Piccini, E. Maggi, G. Trinchieri, and S. Romagnani. 1993. Natural killer cell stimulatory factor (interleukin 12 [IL-12]) induces T helper type 1 (Th1)-specific immune responses and inhibits the development of IL-4-producing Th cells. J. Exp. Med. 177:11991204.

2. Seder, R.A., R. Gazzinelli, A. Sher, and W.E. Paul. 1993. Interleukin-12 acts directly on $\mathrm{CD} 4+\mathrm{T}$ cells to enhance priming for interferon-gamma production and diminishes interleukin-4 inhibition of such priming. Proc. Natl. Acad. Sci. USA. 90:10188-10192.

3. Abbas, A.K., K.M. Murphy, and A. Sher. 1996. Functional diversity of helper T lymphocytes. Nat. 383:787-793.

4. Magram, J., S.E. Connaughton, R.R. Warrier, D.M. Carvajal, C.-Y. Wu, J. Ferrante, C. Stewart, U. Sarmiento, D.A. Faherty, and M.K. Gately. 1996. IL12-deficient mice are defective in IFN $\gamma$ production and type 1 cytokine responses. Immunity. 4:471-481.

5. Via, C.S., V. Rus, M.K. Gately, and F.D. Finkelman. 1994. IL-12 stimulates the development of acute graft-versus-host disease in mice that normally would develop chronic, autoimmune graft-versus-host disease. J. Immunol. 153: 4040-4047.

6. Williamson, E., P. Garside, J.A. Bradley, and A.M. Mowat. 1996. IL-12 is a central mediator of acute graft-versus-host disease in mice. J. Immunol. 157: 689-699.

7. Williamson, E., P. Garside, J.A. Bradley, I.A.R. More, and A.M. Mowat. 1997. Neutralizing IL-12 during induction of murine acute graft-versus-host disease polarizes the cytokine profile toward a Th2-type alloimmune response and confers long term protection from disease. J. Immunol. 159:1208-1215.

8. Sykes, M., G.L. Szot, P.L. Nguyen, and D.A. Pearson. 1995. Interleukin12 inhibits murine graft-vs-host disease. Blood. 86:2429-2438.

9. Yang, Y.-G., J.J. Sergio, D.A. Pearson, G.L. Szot, A. Shimizu, and M. Sykes. 1997. Interleukin-12 preserves the graft-versus-leukemia effect of allogeneic CD8 T cells while inhibiting CD4-dependent graft-versus-host disease in mice. Blood. 90:4651-4660.

10. Yang, Y.-G., B. Dey, J.J. Sergio, and M. Sykes. 1997. IL-12 prevents severe acute GVHD and GVHD-associated immune dysfunction in a full MHC haplotype-mismatched murine bone marrow transplantation model. Transplantation. 64:1343-1352.

11. Dey, B., Y.-G. Yang, G.L. Szot, D.A. Pearson, and M. Sykes. 1998. IL12 inhibits GVHD through a Fas-mediated mechanism associated with alterations in donor T cell activation and expansion. Blood. 91:3315-3322.

12. Nastala, C.L., H.D. Edington, T.G. McKinney, H. Tahara, M.A. Nalesnik, M.J. Brunda, M.K. Getely, S.F. Wolf, R.D. Schreiber, W.J. Storkus, and M.T. Lotze. 1994. Recombinant IL-12 administration induces tumor regression in association with IFN- $\gamma$ production. J. Immunol. 153:1697-1706.

13. Brunda, M.J., L. Luistro, J.A. Hendrzak, M. Fountoulakis, G. Garotta, and M.K. Gately. 1995. Role of interferon- $\gamma$ in mediating the antitumor efficacy of interleukin-12. J. Immunother. 17:71-77.

14. Schijns, V.E.C.J., B.L. Haagmans, and M.C. Horzinek. 1995. IL-12 stimulates an antiviral type 1 cytokine response but lacks adjuvant activity in IFN- $\gamma$ receptor-deficient mice. J. Immunol. 155:2525-2532.

15. Wenner, C.A., M.L. Guler, S.E. Macatonia, A. O'Garra, and K.M. Murphy. 1996. Roles of IFN- $\gamma$ and TNF- $\alpha$ in IL-12-induced T helper cell-1 development. J. Immunol. 156:1442-1447.

16. Szebeni, J., M.-G. Wang, D.A. Pearson, G.L. Szot, and M. Sykes. 1994. IL-2 inhibits early increases in serum gamma interferon levels associated with graft-versus-host disease. Transplantation. 58:1385-1393.

17. Niederwieser, D., M. Herold, W. Woloszczuk, W. Aulitzky, B. Meister, H. Tilg, G. Gastl, R. Bowden, and C. Huber. 1990. Endogenous IFN-gamma during human bone marrow transplantation. Analysis of serum levels of interferon and interferon-dependent secondary messages. Transplantation. 50:620625

18. Allen, R.D., T.A. Staley, and C.L. Sidman. 1993. Differential cytokine expression in acute and chronic murine graft-versus-host disease. Eur. J. Immunol. 23:333-337.

19. Guy-Grand, D., and P. Vassalli. 1986. Gut injury in mouse graft-versus-host reaction: study of its occurrence and mechanism. J. Clin. Invest. 77:1584-1595.
20. Mowat, A.M. 1989. Antibodies to IFN-gamma prevent immunologically mediated intestinal damage in murine graft-versus-host reaction. Immunology. 68:18-23.

21. Brok, H.P.M., P.J. Heidt, P.H. Van der Meide, C. Zurcher, and J.M. Vossen. 1993. Interferon-gamma prevents graft-versus-host disease after allogeneic bone marrow transplantation in mice. J. Immunol. 151:6451-6459.

22. Klimpel, G.R., C.R. Annable, M.G. Cleveland, T.R. Jerrells, and J.C. Patterson. 1990. Immunosuppression and lymphoid hypoplasia associated with chronic graft versus host disease is dependent upon IFN-gamma production. $J$. Immunol. 144:84-93.

23. Holda, J.H., T. Maier, and H.N. Claman. 1988. Evidence that IFNgamma is responsible for natural suppressor activity in GVHD spleen and normal bone marrow. Transplantation. 45:772-777.

24. Wall, D.A., S.D. Hamberg, D.S. Reynolds, S.J. Burakoff, A.K. Abbas, and J.L.M. Ferrara. 1988. Immunodeficiency in graft-versus-host disease. I. Mechanism of immune suppression. J. Immunol. 140:2970-2976.

25. Krenger, W., G. Falzarano, J. Delmonte, K.M. Snyder, J.C.H. Byon, and J.L.M. Ferrara. 1996. Interferon-gamma suppresses T-cell proliferation to mitogen via the nitric oxide pathway during experimental acute graft-versus-host disease. Blood. 88:1113-1121.

26. Brok, H.P., J.M. Vossen, and P.J. Heidt. 1997. Interferon-gamma-mediated prevention of graft-versus-host disease: development of immune competent and allo-tolerant $\mathrm{T}$ cells in chimeric mice. Bone Marrow Transplant. 19: 601-606.

27. Garvy, B.A., F. Gigliotti, and A.G. Harmsen. 1997. Neutralization of interferon-gamma exacerbates pneumocystis-driven interstitial pneumonitis after bone marrow transplantation. J. Clin. Invest. 99:1637-1644.

28. Sykes, M., V.S. Abraham, M.W. Harty, and D.A. Pearson. 1993. IL-2 reduces graft-versus-host disease and preserves a graft-versus-leukemia effect by selectively inhibiting $\mathrm{CD}^{+}{ }^{+} \mathrm{T}$ cell activity. J. Immunol. 150:197-205.

29. Sykes, M., M.L. Romick, K.A. Hoyles, and D.H. Sachs. 1990. In vivo administration of interleukin 2 plus $\mathrm{T}$ cell-depleted syngeneic marrow prevents graft-versus-host disease mortality and permits alloengraftment. J. Exp. Med. 171:645-658.

30. Unkeless, J.C. 1979. Characterization of a monoclonal antibody directed against mouse macrophage and lymphocyte Fc receptors. J. Exp. Med. 150:580596.

31. Taswell, C. 1981. Limiting dilution assays for the determination of immunocompetent cell frequencies. J. Immunol. 126:1614-1619.

32. Antin, J.H., and J.L.M. Ferrara. 1992. Cytokine dysregulation in acute graft-versus-host disease. Blood. 80:2964-2968.

33. Fowler, D.H., K. Kurasawa, A. Husebekk, P.A. Cohen, and R.E. Gress 1994. Cells of the Th2 cytokine phenotype prevent LPS-induced lethality during murine graft-versus-host reaction. Regulation of cytokines and CD8+ lymphoid engraftment. J. Immunol. 152:1004-1013.

34. Krenger, W., K.M. Snyder, J.C.H. Byon, G. Falzarano, and J.L.M. Ferrara. 1995. Polarized type 2 alloreactive CD4+ and CD8+ donor T cells fail to induce experimental acute graft-versus-host disease. J. Immunol. 155:585-593.

35. Krenger, W., K. Snyder, S. Smith, and J.L.M. Ferrara. 1994. Effects of exogenous interleukin-10 in a murine model of graft-versus-host disease to minor histocompatibility antigens. Transplantation. 58:1251-1257.

36. Wall, D.A., and K.C.F. Sheehan. 1994. The role of tumor necrosis factor and interferon gamma in graft-versus-host disease and related immunodeficiency. Transplantation. 57:273-279.

37. Ellison, C.A., J.M.M. Fischer, K.T. HayGlass, and J.G. Gartner. 1998 Murine graft-versus-host disease in an F1-hybrid model using IFN- $\gamma$ gene knockout donors. J. Immunol. 161:631-640.

38. Wang, Z.-E., S. Zheng, D.B. Corry, D.K. Dalton, R.A. Seder, S.L. Reiner, and R.M. Locksley. 1994. Interferon- $\gamma$-independent effects of interleukin-12 administered during acute or established infection due to Leishmania major. Proc. Natl. Acad. Sci. USA. 91:12932-12936.

39. Swihart, K., U. Fruth, N. Messmer, K. Hug, R. Behin, S. Huang, G. Del Giudice, M. Aguet, and J.A. Louis. 1995. Mice from a genetically resistant background lacking the interferon $\gamma$ receptor are susceptible to infection with Leishmania major but mount a polarized $\mathrm{T}$ helper cell 1-type $\mathrm{CD}^{+} \mathrm{T}$ cell response. J. Exp. Med. 181:961-971.

40. Bradley, L.M., D.K. Dalton, and M. Croft. 1996. A direct role of IFN- $\gamma$ in regulation of Th1 cell development. J. Immunol. 157:1350-1358.

41. Dalton, D.K., S. Pitts-Meek, S. Keshav, I.S. Figari, A. Bradley, and T.A. Stewart. 1993. Multiple defects of immune cell function in mice with disrupted interferon-gamma genes. Science. 259:1739-1742.

42. Liu, Y., and C.A. Janeway. 1990. Interferon-gamma plays a critical role in induced cell death of effector T cell: a possible third mechanism of self-tolerance. J. Exp. Med. 172:1735-1739.

43. Novelli, F., F. Di Pierro, P. Francia di Celle, S. Bertini, P. Affaticati, G. Garotta, and G. Forni. 1994. Environmental signals influencing expression of the IFN- $\gamma$ receptor on human T cells control whether IFN- $\gamma$ promotes proliferation or apoptosis. J. Immunol. 152:496-504.

44. Novelli, F., P. Bernabei, L. Ozmen, L. Rigamonti, A. Allione, S. Pestka, G. Garotta, and G. Forni. 1996. Switching on of the proliferation or apoptosis of activated human T lymphocytes by IFN- $\gamma$ is correlated with the differential expression of the $\alpha$ - and $\beta$-chains of its receptor. J. Immunol. 157:1935-1943. 
45. Novelli, F., M.M. D'Elios, P. Bernabei, L. Ozmen, L. Rigamonti, F. Almerigogna, G. Forni, and G. Del Prete. 1997. Expression and role in apoptosis of the alpha- and beta-chains of the IFN-gamma receptor on human Th1 and Th2 clones. J. Immunol. 159:206-213.

46. Konieczny, B.T., Z. Dai, E.T. Elwood, S. Saleem, P.S. Linsley, F.K. Baddoura, C.P. Larsen, T.C. Pearson, and F.G. Lakkis. 1998. IFN- $\gamma$ is critical for long-term allograft survival induced by blocking the CD28 and CD40 ligand T cell costimulation pathways. J. Immunol. 160:2059-2064.

47. Tsutsui, T., J. Mu, M. Ogawa, W.-G. Yu, T. Suda, S. Nagaga, F. Saji, Y. Murata, H. Fujuwara, and T. Hamaoka. 1997. Administration of IL-12 induces a $\mathrm{CD}^{+} \mathrm{CD}^{-} \mathrm{CD} 8{ }^{-} \mathrm{B} 220^{+}$lymphoid population capable of eliciting cytolysis against Fas-positive tumor cells. J. Immunol. 159:2599-2605.

48. Bohm, W., S. Thoma, F. Leithauser, P. Moller, R. Schirmbeck, and J. Reimann. 1998. T cell-mediated, IFN- $\gamma$-facilitated rejection of murine B16 melanomas. J. Immunol. 161:897-908.

49. Brunda, M.J., L. Luistro, R.R. Warrier, R.B. Wright, B.R. Hubbard, M. Murphy, S.F. Wolf, and M.K. Gately. 1993. Antitumor and antimetastatic activity of interleukin 12 against murine tumors. J. Exp. Med. 178:1223-1230.

50. Soiffer, R.J., M.J. Robertson, C. Murray, K. Cochran, and J. Ritz. 1993. Interleukin-12 augments cytolytic activity of peripheral blood lymphocytes from patients with hematologic and solid malignancies. Blood. 82:2790-2796.

51. Rossi, A.R., F. Pericle, S. Rashleigh, J. Janiec, and J.Y. Djeu. 1994. Lysis of neuroblastoma cell lines by human natural killer cells activated by interleu- kin-2 and interleukin-12. Blood. 83:1323-1328.

52. Brunda, M.J., V. Sulich, and D. Bellantoni. 1987. The anti-tumor effect of recombinant interferon alpha and gamma is influenced by tumor location. Int. J. Cancer. 40:807-810.

53. Tannenbaum, C.S., N. Wicker, D. Armstrong, R. Tubbs, J. Finke, R.M Bukowski, and T.A. Hamilton. 1996. Cytokine and chemokine expression in tumors of mice receiving systemic therapy with IL-12. J. Immunol. 156:693-699.

54. Noguchi, Y., A. Jungbluth, E.C. Richards, and L.J. Old. 1996. Effect of interleukin 12 on tumor induction by 3-methylcholanthrene. Proc. Natl. Acad. Sci. USA. 93:11798-11801.

55. Martin, P.J., J.A. Hansen, B. Torok-Storb, D. Durnam, D. Przepiorka, J. O'Quigley, J. Sanders, K.M. Sullivan, R.P. Witherspoon, H.J. Deeg, et al. 1988. Graft failure in patients receiving T cell-depleted HLA-identical allogeneic marrow transplants. Bone Marrow Transplant. 3:445-456.

56. Poynton, C.H. 1988. T cell depletion in bone marrow transplantation. Bone Marrow Transplant. 3:265-279.

57. Butturini, A., and R.P. Gale. 1988. T cell depletion in bone marrow transplantation for leukemia: current results and future directions. Bone Marrow Transplant. 3:185-192.

58. Verdonck, L.F., W.T.M. van Blokland, E.K. Bosboom-Kalsbeek, H.G. Van Heugten, M.G.J. Tilanus, and R.A. de Weger. 1996. Complete donor T cell chimerism is accomplished in patients transplanted with bone marrow grafts containing a fixed low number of T cells. Bone Marrow Transplant. 18:389-395. 